\title{
¿Es realmente un contrato el acuerdo de unión civil?*
}

\section{Mario Alejandro Opazo González}

Resumen: El presente trabajo tiene por finalidad determinar si el acuerdo de unión civil, incorporado a la legislación chilena a través de la Ley n. ${ }^{\circ}$ 20.830, es un contrato patrimonial, como lo señala su artículo primero, o un acto jurídico de derecho de familia. La adopción de una u otra opción redundará en la aplicación del principio de la autonomía privada a dicho contrato. La tesis que se sustenta es que se trata de un acto jurídico de derecho de familia y, como consecuencia de lo anterior, el principio de la autonomía privada aparece muy restringido en este acuerdo, de manera que quienes celebren el acuerdo de unión civil en Chile no podrán alterar el contenido de las disposiciones legales que lo rigen.

Palabras clave: Acuerdo de unión civil, autonomía privada, contrato patrimonial, acto jurídico de derecho de familia, derecho chileno.

\section{Is it Actually a Contract the Civil Union Agreement?}

Aвstract: The present work aims to determine whether the civil union agreement, introduced into the Chilean legislation through the Act number 20.830,

Fecha de recepción: 20 de abril de 2017. Fecha de aceptación: 9 de octubre de 2017. Para citar el artículo: Opazo González, M. A., "¿Es realmente un contrato el acuerdo de unión civil?", Revista de Derecho Privado, Universidad Externado de Colombia, n. ${ }^{\circ} 33$, julio-diciembre de 20I 7, 75-108. DOI: https://doi.org/ro.18601/or 234366.n33.04

** Abogado. Magíster en Derecho, mención Derecho Privado, Universidad de Valparaíso, Chile. Profesor de Derecho Civil universidades Central de Chile y de Valparaíso, Chile. Contacto: mario.opazo@ucentral.cl 
is a patrimonial contract, as it is established by its first article, or a Family Law contract. Assuming one option or the other will lead us into whether it is possible or not to apply the Private Autonomy Principle to this contract. The thesis that it is sustained is that it is a Family Law contract and, therefore, the Private Autonomy Principle appears to be restricted in this agreement, so the people who celebrate the civil union agreement in Chile will not be able to alter the legal rules established for it.

Keywords: Civil union agreement, private autonomy, patrimonial contract, Family Law contract, Chilean Law.

\section{Introducción}

Tradicionalmente se ha señalado que una de las más importantes diferencias que existen entre el derecho civil patrimonial y el derecho de familia se presenta a propósito del principio de la autonomía privada ${ }^{\mathrm{I}}$; en efecto, mientras aquel aparece como el principio rector en materia del derecho civil patrimonial, se encuentra muy disminuido en el ámbito del derecho de familia ${ }^{2}$.

A partir de lo anterior, se ha sostenido que las normas del derecho civil patrimonial serían supletorias de la voluntad de las partes ${ }^{3}$ y, por lo mismo, estas podrían entrar a modificar tales reglas, toda vez que las partes son quienes mejor conocen la forma de satisfacer sus intereses particulares; en cambio, las normas del derecho de familia serían de orden público 4 y, por lo mismo, indisponibles para las partes, toda vez que aparece comprometido el interés general de la sociedad.

I Para estos efectos, siguiendo al profesor Barcia, se entiende que el principio de autonomía privada no solo se refiere a la voluntad como creadora del acto jurídico, sino también a la regulación de sus efectos. Barcia Lehmann, R., "La autonomía privada como principio sustentador de la teoría del contrato y su aplicación en Chile", en De la MAZA, I. (editor), Temas de Contratos. Cuadernos de Análisis Furídicos. Colección Derecho Privado III, Santiago de Chile, Ediciones Universidad Diego Portales, Escuela de Derecho, 2006, i64.

2 El profesor Troncoso sostiene que "en los contratos del derecho de familia [...] las partes no pueden atribuirle efectos diferentes a los que la ley señala y, tampoco, fijarles duración distinta a la establecida por la ley". Troncoso Larronde, H., Contratos, $5 .{ }^{\text {a }}$ ed., Santiago de Chile, Abeledo Perrot, 20 io, i i.

3 Alessandri Rodríguez, A. y Somarriva Undurraga, M., Curso de Derecho Civil. Fuentes de las Obligaciones, Santiago de Chile, Nascimiento, I942, 28.

4 Entre otros: Ramos Pazos, R., Derecho de Familia, 7. ${ }^{a}$ ed., Santiago de Chile, Editorial Jurídica de Chile, t. i, 20r3, r6. En el mismo sentido, López Díaz, C., Tratado de Derecho de Familia, Santiago de Chile, Digesto, 2or6, 20; Troncoso Larronde, H., Derecho de Familia, i6. ${ }^{\mathrm{a}}$ ed., Santiago, Thomson Reuters, 2017 , 3; Court Murasso, E., Curso de Derecho de Familia. Matrimonio - regímenes matrimoniales - uniones de hecho, 2. ${ }^{\mathrm{a}}$ ed., Santiago de Chile, Legal Publishing, 2009, 2; Quintana Villar, M., Derecho de Familia, 2. ${ }^{a}$ ed., Valparaíso, Ediciones Universitarias de Valparaíso, 2015, 24-25. 
Como consecuencia de lo anterior, cabe recordar que, mientras las partes pueden modificar los efectos que produce un acto jurídico patrimonial, ya sea incorporando nuevas obligaciones, o bien cambiando o excluyendo las que establece supletoriamente la ley, lo anterior no es posible en los actos jurídicos de familia, de manera que el consentimiento se reduce a aceptar o rechazar, en su conjunto, los efectos establecidos imperativamente por el legislador.

En este contexto, en Chile, se dicta la Ley n. ${ }^{\circ} 20.830$ que crea el acuerdo de unión civil, figura jurídica que entró en vigencia el 22 de octubre del año $2015^{[5]}$. El artículo r. ${ }^{\circ}$ de dicha ley define este acuerdo como "un contrato celebrado entre dos personas que comparten un hogar, con el propósito de regular los efectos jurídicos derivados de su vida afectiva en común, de carácter estable y permanente". Dado que esta disposición define el acuerdo de unión civil como un contrato, cabe preguntarse si, como contrato que es, ¿̇se rige por el principio de la autonomía privada? Esta es la pregunta que se intentará responder a través de la presente investigación, anticipando, desde ya, que la respuesta sugerida será negativa, pues tanto el articulado de la ley como la historia fidedigna de su establecimiento apuntan a que se trata de un acto jurídico de familia y, por lo mismo, que la autonomía privada aparece muy limitada.

Como consecuencia de lo anterior, debemos entender que las reglas legales sobre el acuerdo de unión civil chileno son imperativas y, por lo mismo, quienes celebren el referido acuerdo no podrán modificarlas válidamente, es decir, las personas que contraigan el acuerdo de unión civil en Chile no podrán alterar las reglas legales establecidas para el referido contrato ${ }^{6}$.

\section{Aspectos generales de la Ley 20.830}

Como es sabido, la Ley n. ${ }^{\circ} 20.830$, de 2 I de abril de 2015 , creó la figura del acuerdo de unión civil; dicha ley entró en vigencia el 22 de octubre del mismo año e incorporó al ordenamiento jurídico chileno un nuevo estatuto familiar ${ }^{7}$.

5 Como explica David Esborraz, el reconocimiento legal de una pluralidad de formas de familia es consecuencia del proceso de internacionalización del derecho, que ha implicado una relectura de las disposiciones legales y constitucionales desde la perspectiva de los derechos fundamentales; concluye que todos estos modelos familiares son dignos de tutela jurídica. Esborraz, D., "El concepto constitucional de familia en América Latina. Tendencias y proyecciones", Revista de Derecho Privado, Universidad del Externado de Colombia, n. ${ }^{\circ}$ 29, 20 I 5, 30-3 I.

6 Lo anterior no debiera extrañarnos, toda vez que -como dice Juan Carlos Guarín Ferrer- en la actualidad se reconoce que los derechos tienen límites. Guarín Ferrer, J., "Autonomía de la voluntad en los contratos de consumo", Ratio Iuris. Revista de Derecho Privado, Universidad de Ciencias Empresariales y Sociales de la Ciudad Autónoma de Buenos Aires, vol. 2, n. ${ }^{\circ}$ 2, 20 I4. Por lo mismo, la autonomía privada también puede ser limitada por la ley en los actos jurídicos de familia, como ocurre con el acuerdo de unión civil chileno.

7 El profesor Lepin sostiene que incorporó un nuevo estatuto jurídico, que regula las relaciones de pareja, pero que es distinto del matrimonio. Lepin Molina, C., Derecho Familiar Chileno, Santiago de Chile, Thomson Reuters, 20 I 7, p. 3 i 6. 
Originalmente, el proyecto buscaba solucionar los problemas patrimoniales que sufrían más de dos millones de parejas que convivían de hecho ${ }^{8}$; de ahí que regulaba principalmente relaciones patrimoniales. En ese contexto, el proyecto del entonces senador Allamand 9 establecía, en su texto original, que el denominado en esa época acuerdo de vida en común buscaba regular las relaciones de convivencia en un hogar común, con voluntad de permanencia y ayuda mutua. Como consecuencia de lo anterior, dicho proyecto establecía solamente relaciones jurídicas entre los contratantes y no entre uno de ellos y los consanguíneos del otro; el contrato debía celebrarse por escritura pública; solo se establecía el deber de ayuda mutua; también establecía que -por regla general- cada contratante conservaría el dominio y administración de todos sus bienes, cualquiera que fuese la época de adquisición, y que solo excepcionalmente procedería una comunidad de gananciales, si las partes decidían someterse a ella; regulaba las obligaciones contraídas frente a terceros, y establecía derechos hereditarios para los contratantes, incluyendo un derecho de adjudicación preferente.

Sin embargo, como se hizo presente por parte de las personas que intervinieron en la discusión habida en la Comisión de Constitución del Senado, ello implicaba que las personas debían suscribir la escritura pública para quedar amparadas por la ley y, por lo mismo, seguiría habiendo parejas que no suscribirían dicha escritura pública, es decir, seguirían siendo parejas de hecho, por lo que -en definitiva- el problema que se buscaba solucionar no sería solucionado ${ }^{\mathrm{Io}}$.

Conforme se examinará, a lo largo de la tramitación del proyecto de ley esta idea original fue modificándose, ampliándose considerablemente los efectos que genera el acuerdo de unión civil, excediendo con creces el ámbito estrictamente patrimonial. Con todo, puede advertirse que -por una parte- esta figura trata de asemejarse al matrimonio, de manera que se configura como una alternativa para aquellas parejas del mismo sexo que, si bien buscan su aceptación social a través de un reconocimiento de su estatus familiar, no pueden acceder al vínculo matrimonial, y-por otra parte- busca distanciarse del matrimonio, para que este conserve una fisonomía distintiva, reservado solamente para parejas de distinto sexo. Sin perjuicio de la discusión habida durante la tramitación del proyecto de ley, en orden a determinar si el acuerdo sería aplicable únicamente a parejas del mismo sexo o a parejas de distinto sexo, el texto definitivo estableció que tanto parejas del mismo sexo como parejas de distinto sexo podrían acceder a este contrato.

8 Historia de la Ley, 3. Disponible en http://www.bcn.cl/historiadelaley/nc/historia-de-laley/3990. Última consulta: 20 de enero de 20 I 7.

9 Boletín n. ${ }^{\circ}$ 7.0 I I - o7.

Io Historia de la Ley, n. ${ }^{\circ}$ 9, p. I62. 


\section{Planteamiento del problema}

Como se anticipó, el problema surge por cuanto la definición legal del acuerdo de unión civil señala que se trata de un contrato. El solo tenor literal del artículo I..$^{\circ}$ de la Ley n. ${ }^{\circ} 20.830$ debiera ser suficiente para sostener su naturaleza contractual y, como consecuencia de ello, afirmar que el principio de la autonomía privada rige en plenitud, sin otros límites que los establecidos por la ley, el orden público y las buenas costumbres. Sin embargo, en el ámbito doctrinario es posible encontrar dos opiniones en relación con este tema.

Por una parte, el profesor Jorge Del Picó ${ }^{\text {I }}$ sostiene que uno de los principios que rige la Ley n. ${ }^{\circ} 20.830$ es el de la autonomía de la voluntad (moral y contractual), en virtud del cual los individuos tienen el derecho de vincularse y de obligarse libremente entre sí, "sin intervención externa en la causa y calificación del contenido del vínculo establecido, sin coacción imperativa o prohibitiva por parte del Estado y sus agentes"; de esta manera se enfatiza el carácter privatista y no institucional del acuerdo de unión civil. Agrega que la naturaleza contractual del acuerdo de unión civil, en su concepto, no es discutida y, por tanto, se aplican, en su caso, tanto la teoría general del contrato como las disposiciones legales contenidas en el Código Civil, generando para los convivientes los derechos y obligaciones que la ley establece ${ }^{\mathrm{I} 2}$. Consecuente con lo anterior, las partes serían libres para determinar el contenido de este acuerdo, reconociéndose, implícitamente, que las disposiciones de la Ley n. ${ }^{\circ} 20.830$ serían supletorias de la voluntad de las partes.

Por otro lado, el autor Carlos López sostiene que, si bien el acuerdo de unión civil es un contrato, según lo señala la definición del artículo r. ${ }^{\circ}$ de la Ley n. ${ }^{\circ} 20.830$, se trata de un contrato que tiene características propias y autóno$\operatorname{mas}^{\mathrm{I} 3} \mathrm{y}$, por lo mismo, se sujeta a reglas especiales ${ }^{\mathrm{I} 4}$, de manera que considera que es un error afirmar que al acuerdo de unión civil son aplicables las reglas de existencia y validez del acto jurídico patrimonial, toda vez que se trata de una institución con rasgos suficientemente originales que permiten sostener que sus requisitos son autónomos ${ }^{15} \mathrm{y}$, por lo mismo, cabría concluir que no se rige por las reglas de los contratos patrimoniales, de manera que no tiene cabida el principio de la autonomía privada.

i I Del Picó Rubio, J., “El acuerdo de unión civil: concepto, elementos y efectos del régimen civil de las uniones afectivas de convivencia en la Ley n. ${ }^{\circ} 20.830$ ", Revista de Derecho de Familia, vol. I, n. ${ }^{\circ}$ 9, Santiago, Thomson Reuters, 2016, I 3.

i Del Picó Rubio, J. (n. I2), i4.

I 3 López Díaz, C. (n. 5), 96.

I4 López Díaz, C. (n. 5), 97.

i 5 López Díaz, C. (n. 5), 98. 
Frente a esta discusión, conforme se observará, existen varios argumentos que permiten sostener que el acuerdo de unión civil es un acto jurídico de derecho de familia ${ }^{16} \mathrm{y}$, por consiguiente, no rige completamente en él el principio de la autonomía privada, toda vez que las disposiciones legales que lo regulan son imperativas ${ }^{17}$.

\section{Razones que permiten sostener que el acuerdo de unión civil es un acto jurídico de familia}

Si bien la ley se limita a decir que el acuerdo de unión civil es un contrato, existen diversos argumentos que permiten sostener que se trata de un acto jurídico de derecho de familia, los cuales pueden ser agrupados de la siguiente manera:

\section{El contexto de la ley}

Según el artículo 22 del Código Civil chileno, el contexto de la ley sirve como elemento de interpretación, toda vez que el intérprete debe usarlo procurando que entre todas las partes exista la debida correspondencia y armonía.

De esta manera, si se interpreta armónicamente el articulado de la Ley n. ${ }^{\circ}$ 20.830, se llegará a la conclusión que el acuerdo de unión civil es un acto jurídico de familia, debido a las siguientes razones:

r. . El artículo r. ${ }^{\circ}$ inciso r. ${ }^{\circ}$ de la Ley n. ${ }^{\circ}$ 20.830, al definir el acuerdo de unión civil, señala que regula los efectos jurídicos derivados de su vida afectiva en común. El empleo de la expresión afectiva da a entender que no se trata de un contrato que reglamente relaciones jurídicas patrimoniales, pues la afectividad es ajena a este tipo de relaciones.

I.2. La misma disposición agrega que los convivientes civiles serán considerados parientes para los efectos previstos en el artículo 42 del Código Civil ${ }^{18}$. De

i6 Para estos efectos, siguiendo a Nidia Gallegos, se entiende que el acto jurídico familiar se refiere a las relaciones personales, que le dan una característica especial, y de estas relaciones personales se derivan relaciones patrimoniales o económicas. Gallegos, N., La teoría del hecho y acto jurídico aplicada al derecho familiar, Tabasco, Editorial de la Universidad Juárez Autónoma de Tabasco, 2006, I23.

I7 Como nos recuerda el profesor Hinestrosa, la autonomía privada comprende la libertad de contratar o no, de escoger a la contraparte, escoger la figura iuris, intervenir personalmente o a través de un intermediario, escoger la forma de expresión y determinar el contenido de la disposición. Hinestrosa, F., "Autonomía privada y tipicidad contractual”, Revista de Derecho Privado, Universidad del Externado de Colombia, n. ${ }^{\circ}$ 24, 20I3, 9. De esta manera, la autonomía privada tendría alguna cabida en el acuerdo de unión civil chileno, toda vez que se puede elegir contratar o no, escoger a la contraparte, escoger celebrar un acuerdo de unión civil, hacerlo personalmente o a través de mandatario; pero no se puede escoger la forma de expresión ni determinar el contenido de la disposición.

I8 Art. 42 C. C.: "En los casos en que la ley dispone que se oiga a los parientes de una persona, se entenderán comprendidos en esa denominación el cónyuge de ésta y sus consanguíneos de uno 
esta manera, resulta evidente que se trata de un acto jurídico de familia, pues los contratos patrimoniales no generan parentesco entre las partes que lo celebran.

I.3. El artículo I. ${ }^{\circ}$ inciso $2 .^{\circ}$ de la misma ley señala que los convivientes civiles adquieren el estado civil de conviviente civil. Nuevamente, resulta evidente que estamos frente a un acto jurídico de familia y no frente a un contrato patrimonial, pues estos no dan origen a un nuevo estado civil.

I.4. El artículo $3 .^{\circ}$ de la ley señala que este acuerdo no puede sujetarse a plazo, condición ni modo alguno; tampoco puede ser objeto de un contrato de promesa. Esta característica es propia de los actos y derechos de familia ${ }^{\mathrm{I} 9}$.

I.5. El artículo $4 .^{\circ}$ de la ley crea un parentesco por afinidad entre un conviviente civil y los consanguíneos de la persona con la que esté unida por un acuerdo de unión civil; se trata de un parentesco por afinidad curioso, pues no subsiste una vez terminado el acuerdo ${ }^{20}$. En consecuencia, el acuerdo de unión civil no puede ser considerado como un contrato patrimonial, puesto que crea un parentesco por afinidad, cuestión completamente ajena a los contratos patrimoniales.

I.6. El artículo $5 .^{\circ}$ de la ley señala que este contrato debe celebrarse en el Servicio de Registro Civil e Identificación, lo que está demostrando que no puede tratarse de un contrato patrimonial, pues, en tal caso, se debería celebrar por escritura pública o se hubiese establecido otra solemnidad propia de los actos patrimoniales; sin embargo, el legislador optó por exigir que el acuerdo fuese celebrado ante un representante de la Administración del Estado, encargado, precisamente, de registrar los hechos y actos significativos para las personas y que influyen en el estado civil de estas.

I.7. El artículo $5 .^{\circ}$ de la ley exige, como requisito para la celebración de este contrato, que los contrayentes declaren, bajo juramento o promesa, acerca del hecho de no encontrarse ligados por vínculo matrimonial no disuelto o un acuerdo de unión civil vigente. Aquí se advierte una verdadera unidad del vínculo, toda vez que los convivientes civiles solo pueden ser dos personas ${ }^{21}$, es decir, la ley impi-

y otro sexo, mayores de edad. A falta de consanguíneos en suficiente número serán oídos los afines.

Serán preferidos los descendientes y ascendientes a los colaterales, y entre éstos los de más cercano parentesco.

Los parientes serán citados, y comparecerán a ser oídos, verbalmente, en la forma prescrita por el Código de Enjuiciamiento".

i9 Court Murasso, E. (n. 5), 3 .

20 Según el art. 3 I inciso I. ${ }^{\circ}$ del Código Civil, el parentesco por afinidad es el que existe entre una persona que está o ha estado casada y los consanguíneos de su marido o mujer, es decir, de conformidad con dicha disposición, el parentesco por afinidad subsiste después de haberse terminado el matrimonio.

2 I Garrido Chacana, C., Acuerdo de Unión Civil. Análisis de la Ley 20.83o, Santiago de Chile, Metropolitana, $20 \mathrm{I}_{5}, 6_{3}$. 
de la pluralidad de partes $^{22}$. Esta característica se puede explicar únicamente si estamos en presencia de un acto jurídico de derecho de familia, pues no existe ninguna razón para que la ley exija exclusividad, cuando estamos frente a un contrato patrimonial ${ }^{23}$.

I.8. El artículo $6 .^{\circ}$ inciso I. $^{\circ}$ de la ley señala, como requisitos para la celebración de este acuerdo, que el oficial del Registro Civil levante un acta y que esta sea inscrita en un registro especial que llevará el Servicio de Registro Civil e Identificación. Esta disposición establece que, para que el acuerdo de unión civil nazca a la vida del derecho, no basta con su celebración ante un oficial del Registro Civil, esto es, ante un representante de la autoridad estatal, sino que, además, se precisa que dicho oficial inscriba el acuerdo celebrado en un registro especial que lleva el mismo; de esta manera, resulta claro que estamos en presencia de un acto jurídico de derecho de familia, pues, si fuese un mero contrato patrimonial, no se justificaría que este acuerdo fuese inscrito en un registro público donde se consignan aquellos hechos y actos jurídicos que inciden en el estado civil de las personas.

En este sentido, el profesor Pablo Cornejo sostiene, al referirse al reconocimiento de la validez en Chile de los acuerdos celebrados en el extranjero, que la finalidad que suele perseguir el registro es proporcionar una razón adicional para considerar que el acuerdo es un acto jurídico familiar y no un mero contrato celebrado entre las partes, debido a la importancia que tienen los registros en materia de estado civil y familia ${ }^{24}$.

I.9. El artículo i 4 de la ley, al referirse a los efectos del acuerdo, señala que los convivientes civiles se deberán ayuda mutua y que están obligados a solventar los gastos generados por su vida en común, de conformidad a sus facultades económicas y al régimen patrimonial que entre ellos exista. A partir de esta disposición, es posible extraer dos argumentos adicionales para sostener que el acuerdo de unión civil es un acto jurídico de familia: por una parte, el deber de ayuda mutua y la obligación de solventar los gastos generados por su vida en común constituyen deberes personales propios del derecho de familia; por otra parte, la referencia a la existencia de un régimen patrimonial da cuenta de que estamos

López Díaz, C., El Acuerdo de Unión Civil, Santiago de Chile, El Jurista, 201 5, 25. Es lo que profesor Del Picó denomina excluir la pluralidad de vínculos. Del Picó Rubio, J. (n. I2), i 4.

23 Una cosa distinta es que las partes, atendidas a diversas consideraciones, puedan exigir exclusividad; pero, en tales casos, la exclusividad se incorpora al contrato a través de una cláusula especial, es decir, se trata de un elemento accidental del contrato que se agrega por un acuerdo de las voluntades de las partes. Esto es lo que ocurre en ciertos contratos mercantiles, como el contrato de distribución, el contrato de concesión mercantil y el contrato de franquicia. SANdoval López, R., Contratos mercantiles, Santiago de Chile, Editorial Jurídica de Chile, 2003, 545, $55^{6,}, 575$.

24 Cornejo Aguilera, P., "Acuerdo de unión civil y derecho internacional privado", en Hernández Paulsen, G. y Tapia Rodríguez, M. (coordinadores), Estudios sobre la nueva Ley de Acuerdo de Unión Civil, Santiago de Chile, Thomson Reuters, 2016, 95. 
frente a un acto de derecho de familia, pues estos dan origen a un régimen patrimonial, no así los actos patrimoniales ${ }^{25}$.

I. Io. El artículo I 5 inciso final de la ley hace aplicables, a los convivientes civiles, las reglas sobre declaración de bien familiar contenidas en el Código Civil.

El autor Carlos López entiende que la institución de los bienes familiares busca proteger el patrimonio familiar y fue incorporada al ordenamiento jurídico chileno a través de la Ley n. ${ }^{\circ}$ I 9.335, la cual estableció que el cónyuge propietario del inmueble que sirva de residencia principal de la familia y los muebles que lo guarnecen no puede, en virtud de una declaración judicial, enajenar ni gravar voluntariamente, ni prometer enajenar o gravar dichos bienes, mientras no medie el consentimiento del cónyuge no propietario ${ }^{26}$.

En un sentido similar, el profesor Ramos sostiene que el fundamento de esta institución se encuentra en asegurar a la familia un hogar físico estable donde sus integrantes puedan desarrollar la vida con normalidad, especialmente cuando los cónyuges se encuentran separados; de esta manera se evita que las disputas patrimoniales entre los cónyuges terminen con el desarraigo de la residencia principal de la familia ${ }^{27}$.

Referido al acuerdo de unión civil, debiéramos entender que se trata de una institución que busca proteger al conviviente civil no propietario, toda vez que el conviviente civil propietario del inmueble que sirva de residencia principal de la familia y de los muebles que lo guarnecen no podrá, en virtud de una declaración judicial, enajenar ni gravar voluntariamente, ni prometer enajenar o gravar dichos bienes, mientras no medie el consentimiento del conviviente civil no propietario. Se advertirá que esta institución adquiere gran importancia si consideramos la fragilidad de este acuerdo, toda vez que puede terminar por voluntad unilateral de cualquiera de los convivientes civiles.

Como se ha resaltado, la facultad de pedir la declaración de bien familiar es un efecto del acuerdo de unión civil $^{28} \mathrm{y}$, dado que se trata de una institución que tiene por objeto proteger el patrimonio familiar, es dable sostener que el acuerdo de unión civil es un acto jurídico de derecho de familia ${ }^{29}$.

25 Con todo, reconocemos que este punto es discutible, pues -como señala el profesor Manuel Barría- no resulta claro del articulado de la ley si, en rigor, estamos o no frente a un régimen patrimonial. Barría Paredes, M., “¿Régimen? de comunidad en el acuerdo de unión civil. Algunas consideraciones sobre su administración y responsabilidad”, en Corral, H. y Manterola, P. (editores), Estudios de Derecho Civil XII. Ponencias presentadas en las XIV Fornadas Nacionales de Derecho Civil, 6 y 7 de octubre de 20I6, Maitencillo, Santiago de Chile, Thomson Reuters, 20I7, 59-72.

26 López Díaz, C. (n. 22), 7 I.

27 Ramos Pazos, R. (n. 5), 359.

28 López Díaz, C. (n. 22), 65.

29 El autor Carlos Garrido sostiene que, en virtud de esta institución, se pretende garantizar a la familia de los convivientes civiles un hogar físico y estable donde sus integrantes puedan 
I.I I. El artículo I6 de la Ley n. ${ }^{0} 20.830$ señala que el conviviente civil será considerado como beredero intestado y legitimario del otro y concurrirá en su sucesión de la misma forma y gozará de los mismos derechos que corresponden al cónyuge sobreviviente. Agrega que el conviviente civil podrá también ser asignatario de cuarta de mejoras.

En relación con el fundamento de la sucesión intestada, el profesor Elorriaga sostiene que la ley, a la hora establecer qué personas han de suceder al causante, considera los naturales grados de afecto que se tienen respecto de los demás y también los que se reputan como parientes más cercanos del causante ${ }^{3}$.

Como ha explicado la doctrina, antes de la entrada en vigencia de la Ley n. ${ }^{\circ}$ 20.830, el legislador consagraba dos tipos de relaciones para hacer el llamamiento: la relación conyugal y la relación consanguínea; la única excepción que contemplaba la ley era la situación del adoptado, quien es considerado como un hijo y, por lo mismo, a través de una ficción legal, es asimilado en todo a los hijos ${ }^{3}{ }^{3} 3^{2}$. Como puede advertirse, son las relaciones de familia las que ha considerado la ley para los efectos de determinar quiénes serán llamados a suceder por causa de muerte a una persona 33 .

Después de la entrada en vigencia de la Ley n. ${ }^{\circ} 20.830$, debemos agregar al acuerdo de unión civil como nueva fuente del llamamiento que hace la ley para la sucesión intestada. En consecuencia, es posible sostener que el acuerdo de unión civil también es una fuente de relaciones familiares y, por lo mismo, que dicho acuerdo es un acto jurídico de familia.

Por otro lado, la disposición en comento confiere al conviviente civil sobreviviente la calidad de legitimario. Como explica el profesor Rodríguez, las legítimas están ordenadas a favor de ciertas personas, llamadas legitimarios, a quienes la ley presume que son las personas más próximas y entrañables del causante ${ }^{34}$; es decir, a los familiares más cercanos del causante. Luego, si el conviviente civil tiene la calidad de legitimario, es porque la ley lo considera como un familiar muy cercano del causante, lo que a su turno permite sostener que el acuerdo de unión civil es un acto jurídico de derecho de familia.

desarrollar su vida habitual con normalidad, aun después de disuelto el acuerdo de unión civil. Garrido Chacana, C. (n. 2 I), ioo.

30 Elorriaga De Bonis, F., Derecho sucesorio, 3. ${ }^{a}$ ed., Santiago de Chile, Thomson Reuters, 20 I 5 , I40.

3 I Rodríguez Grez, P., Instituciones de Derecho Sucesorio, 3. ${ }^{a}$ ed., Santiago de Chile, Editorial Jurídica de Chile, vol. I, 2006, 252.

32 Con todo, hay una excepción que subsiste hasta el día de hoy y que corresponde al llamamiento que hace la ley al Fisco.

33 En este sentido, el profesor Gonzalo Ruz sostiene que "los llamados a suceder pertenecerán al círculo más íntimo de la familia y a falta de ellos a los círculos familiares más alejados”. Ruz Lártiga, G., Explicaciones de Derecho Civil. Sucesiones y liberalidades, Santiago de Chile, Editorial Jurídica de Chile, t. vi, $2014,234$.

Rodríguez Grez, P. (n. 32), 306. 
Lo anterior se ve reforzado por el hecho de considerarse al conviviente civil como posible asignatario de cuarta de mejoras, pues, como señala el profesor Rodríguez, la finalidad de la cuarta de mejoras es que el causante pueda mejorar a cualquier legitimario e incluso a una persona que, sin tener tal calidad, pueda llegar a tenerla ${ }^{35}$. En consecuencia, el hecho de considerarlo como posible asignatario de cuarta de mejoras implica que tiene la calidad de familiar, a quien la ley autoriza a que pueda quedar en mejor posición que otros familiares, de lo que se desprende, a su turno, que el acuerdo de unión civil es un acto jurídico de familia.

I.I 2. El artículo 22 inciso I. ${ }^{\circ}$ de la Ley n.$^{\circ} 20.830$ señala que los asuntos a que se refiere el artículo $8 .^{\circ}$ de la Ley n. ${ }^{\circ}$ i $9.968^{[36]}$, que se promuevan entre los convivientes civiles, deberán ser conocidos por el juez con competencia en materias de familia. Esta disposición viene a reforzar la opinión que sostiene que el acuerdo de unión civil es un acto jurídico de familia, pues, si fuese un contrato que se rige por las reglas de los contratos patrimoniales, no se comprendería por qué los conflictos que surjan entre los convivientes civiles, cuando se refieran a las materias que son de competencia de los tribunales de familia, deban ser conocidos por dichos tribunales.

I.I3. El artículo 23 de la Ley n. ${ }^{\circ} 20.830$ señala que todas las inhabilidades, incompatibilidades y prohibiciones que las leyes y reglamentos establecen respecto de los cónyuges se harán extensivas, de pleno derecho, a los convivientes civiles. Esta disposición se justifica solo en la medida en que se entienda que la relación que surge del acuerdo de unión civil es de naturaleza familiar; por consiguiente, el acuerdo de unión civil únicamente puede ser considerado como un acto jurídico de familia y no puede ser entendido como un contrato patrimonial, en el que prime el principio de la autonomía privada.

I.I4. El artículo 27 de la ley hace procedente la compensación económica, cuando uno de los convivientes civiles, por haberse dedicado al cuidado de los hijos o a las labores propias del hogar común, no pudo desarrollar una actividad remunerada o lucrativa durante la vigencia del acuerdo o lo hizo en menor medida de lo que podía y quería. En tal caso, tendrá derecho a que, cuando se produzca la terminación del acuerdo por ciertas causales establecidas expresamente por la ley, se le compense el menoscabo económico sufrido por esta causa.

Como puede advertirse, la reglamentación de esta institución que hace la Ley.$^{\circ} 20.830$ es muy similar a la que establece el artículo 6r de la Ley n. ${ }^{\circ}$ I9.947 para el matrimonio. No obstante que la doctrina ha discutido mucho respecto de la definición y naturaleza jurídica de la compensación económica, es

35 Rodríguez Grez, P. (n. 32), 359. En el mismo sentido, Domínguez Benavente, R. y Domínguez Águila, R., Derecho Sucesorio, 3. ${ }^{a}$ ed., Santiago de Chile, Editorial Jurídica de Chile, t. II, $2011,956$.

36 La Ley n. ${ }^{\circ}$ i 9.968 crea los tribunales de familia. 
posible encontrar algunas ideas que permiten sostener que el acuerdo de unión civil es un acto jurídico de derecho de familia.

Así, por ejemplo, el profesor Ruz sostiene que el fundamento de la compensación económica se encuentra en la protección de la familia ${ }^{37}$, pues, como explican los profesores Pizarro y Vidal, la compensación económica se justifica en la medida en que se produce una pérdida del estatuto protector del matrimonio que perjudica a uno de los cónyuges. En efecto, la compensación económica surge por cuanto uno de los cónyuges se ha dedicado al cuidado de la familia, mientras que el otro pudo desarrollar una actividad remunerada o lucrativa; en el contexto del matrimonio, tales hechos son irrelevantes, atendido el estatuto protector del matrimonio y en el entendido que la comunidad que se forma por el matrimonio era para toda la vida ${ }^{3}$; esta confianza en que el matrimonio es para toda la vida merece una especial protección; de esta manera, si ello no se cumple, una vez terminado el matrimonio, los hechos aludidos son de trascendental importancia, pues se traducen en que aquel cónyuge que no desarrolló una actividad remunerada o lucrativa, o lo hizo en menor medida de lo que podía y quería, quedará en una situación de precariedad económica. De esta manera, la compensación tiene por finalidad dejar a ese cónyuge en una situación similar a aquella en que se encontraría, para enfrentar el futuro, de no haberse dedicado al cuidado de la familia durante el matrimonio ${ }^{39-40}$. Con la entrada en vigencia de la Ley n. ${ }^{\circ} 20.830$, lo mismo cabría sostener respecto del conviviente civil ${ }^{4 \mathrm{I}}$.

37 Ruz Lártiga, G., Explicaciones de Derecho Civil. Derecho de las personas en familia, Santiago de Chile, Editorial Jurídica de Chile, t. v, 20 I 2, i6o. En el mismo sentido, Barcia Lehmann, R., Fundamentos del Derecho de Familia y de la Infancia, Santiago de Chile, Thomson Reuters, 2OI 2, 3I 7 .

38 Vidal Olivares, A., "La compensación por menoscabo económico en la Ley de Matrimonio Civil", en vv. AA., El nuevo derecho chileno del matrimonio, Santiago de Chile, Editorial Jurídica de Chile, 2006, 229.

39 Pizarro Wilson, C. y Vidal Olivares, A., La compensación económica por divorcio o nulidad matrimonial, Santiago de Chile, Abeledo Perrot, $3 .{ }^{a}$ ed., 20 Io, I 7.

40 En el mismo sentido se pronuncia el profesor Corral, al señalar que la función de la compensación económica "es servir de morigeración o paliativo del desamparo económico en que queda esta mujer que, confiando en la promesa matrimonial del marido, invirtió todos sus esfuerzos en sacar adelante la familia, y ahora ve que la ley autoriza a que, sin su voluntad, le prive completamente del estatuto protector del matrimonio" (la cursiva es nuestra). Corral Talciani, H., Separación, nulidad y divorcio. Análisis desde los principios y las reglas de la ley de matrimonio civil, Santiago de Chile, Thomson Reuters, 201 I 92.

4I Vidal Olivares, Á., “¿Se justifica el reconocimiento de la compensación económica en el acuerdo de unión civil?", en Acuña San Martín, M. y Del Picó Rubio, J. (editores), Estudios de Derecho Familiar. Segundas fornadas Nacionales de Derecho de Familia, Talca, Editorial Universidad de Talca, 20 I 7, I I 5-I 2 I. 


\section{La historia fidedigna del establecimiento de la ley}

El artículo I9 inciso segundo del Código Civil chileno contempla la historia fidedigna del establecimiento de la ley como otro elemento de interpretación. A partir de lo anterior, si se examina la historia de la tramitación parlamentaria de la Ley n. ${ }^{\circ}$ 20.830, se podrá advertir que la intención del legislador fue la de concebir un acto jurídico de familia.

\section{I. Los primeros proyectos}

2.I.r. Tanto el Mensaje que el presidente Piñera enviara al Congreso Nacional para la creación del entonces denominado acuerdo de vida en pareja (Boletín n. ${ }^{\circ}$ 7.873 - 07) como la Moción presentada por el senador Andrés Allamand para crear el acuerdo de vida en común (Boletín n. ${ }^{\circ} 7.0$ I I - 07) ${ }^{42}$ dan cuenta de una intención de crear un contrato que regulase mayoritariamente las consecuencias patrimoniales entre las partes que lo celebrasen ${ }^{43}$, la que se manifestaba en que:

2.I.I.I. Para su celebración se exigía escritura pública (proyectos del senador Allamand y del Ejecutivo44).

2.I.I.2. El contrato establecía solamente relaciones jurídicas entre los contratantes, pero no entre uno de estos y los consanguíneos del otro (proyecto del senador Allamand ${ }^{45}$ ).

2.I.I.3. La celebración de este contrato no alteraría el estado civil de los contratantes (proyectos del senador Allamand y del Ejecutivo ${ }^{4}$ ), es decir, no generaba un nuevo estado civil47.

2.I.I.4. La expiración del acuerdo pondría fin a las obligaciones y derechos de carácter patrimonial (el énfasis es nuestro) cuya titularidad y ejercicio se funde en la vigencia del acuerdo (proyectos del senador Allamand y del Ejecutivo ${ }^{4}$ ).

2.I.I.5. Concedía competencia para conocer de los asuntos a que dé lugar este contrato al juez de letras del domicilio de cualquiera de las partes (proyecto del senador Allamand y proyecto del Ejecutivo49), entendiéndose la referencia al juez de letras en lo civil $5^{\circ}$.

Historia de la Ley n. ${ }^{\circ}$ 20.830, cit. (n. 9), 3.

43 Historia de la Ley n. ${ }^{\circ} 20.830$, cit. (n. 9), I3.

44 Historia de la Ley n. ${ }^{\circ} 20.830$, cit. (n. 9), 6 y г 6.

45 Historia de la Ley n. ${ }^{\circ} 20.830$, cit. (n. 9), 6.

46 Historia de la Ley n. ${ }^{\circ} 20.830$, cit. (n. 9), 6 y г 6.

47 Así lo recalca el profesor Mauricio Tapia en Historia de la Ley n. ${ }^{\circ}$ 20.830, cit. (n. 9), 79.

48 Historia de la Ley n. ${ }^{\circ} 20.83$ o, cit. (n. 9), 8 y г 8.

49 Historia de la Ley n. ${ }^{\circ} 20.830$, cit. (n. 9), 9 y г 8.

50 Así lo entendió la Corte Suprema. Historia de la Ley n. ${ }^{\circ}$ 20.830, cit. (n. 9), 27. 
2.I.I.6. Ninguno de estos proyectos contemplaba la posibilidad de la declaración de bien familiar ${ }^{\mathrm{I}}$.

2.r.2. Con todo, en el proyecto del senador Allamand se advertía la existencia de determinados atisbos del carácter familiar de este contrato:

2.I.2.I. El acuerdo de vida en común era definido como un contrato celebrado por dos personas naturales, mayores de edad, para regular sus relaciones de convivencia en un hogar común, con voluntad de permanencia y ayuda mutua (el énfasis es nuestro) $)^{52}$.

2.I.2.2. La escritura pública de constitución debía inscribirse en un registro especial a cargo del Servicio de Registro Civil53.

2.r.2.3. Impedía que este acuerdo lo pudieran celebrar, entre sí, los ascendientes y descendientes por consanguinidad, y los colaterales por consanguinidad en el segundo grado54.

2.r.2.4. Prescribía que no podían celebrar este contrato quienes estuvieren ligados por vínculo matrimonial no disuelto o por otro acuerdo de unión civil que se encuentre vigente 55 .

2.r.2.5. Decía que los contratantes se debían, recíprocamente, ayuda mu$\operatorname{tua}^{56}$.

2.I.2.6. Concedía ciertos derechos hereditarios al contratante sobreviviente: lo consideraba como heredero concurrente en el primer orden de sucesión, en el cual tenía derecho a una porción equivalente a la que correspondía a cada hijo, de manera que no tenía asegurada la cuarta parte de la herencia o de la mitad legitimaria, en su caso; era considerado como heredero determinante en el segundo orden, junto con los ascendientes, debiendo la herencia dividirse por mitades: una para el contratante y la otra para los ascendientes, y podía asignársele el total o una parte de la cuarta de mejoras ${ }^{57}$.

2.I.2.7. Al contratante sobreviviente se le reconocía un derecho de adjudicación preferente, semejante al que la regla io. ${ }^{a}$ del artículo I.337 del Código Civil concede al cónyuge sobreviviente, con la salvedad que no podía pedir la constitución de los derechos de uso y habitación gratuitos y vitalicios que la referida disposición sí concede al cónyuge sobreviviente $5^{8}$.

2.r.3. Por su parte, el proyecto del Ejecutivo definía el acuerdo de vida en pareja como un contrato celebrado entre dos personas con el propósito de re-

Así lo hizo presente el profesor Mauricio Tapia en Historia de la Ley n. ${ }^{20.830}$, cit. (n. 9), 7 I .

Historia de la Ley n. ${ }^{\circ} 20.830$, cit. (n. 9), 6.

Historia de la Ley n. ${ }^{\circ} 20.830$, cit. (n. 9), 5 .

Historia de la Ley n. ${ }^{\circ} 20.830$, cit. (n. 9), 6.

Historia de la Ley n. ${ }^{\circ} 20.830$, cit. (n. 9), 6.

Historia de la Ley n. ${ }^{\circ} 20.830$, cit. (n. 9), 7 .

Historia de la Ley n. ${ }^{\circ} 20.830$, cit. (n. 9), 7.

Historia de la Ley n. ${ }^{\circ} 20.830$, cit. (n. 9), 7. 
gular los efectos jurídicos derivados de su vida afectiva en común (el énfasis es nuestro) 59 .

Como es sabido, ambos proyectos fueron refundidos y dicho texto refundido fue el que se sometió a discusión en el Congreso Nacional ${ }^{60}$.

\subsection{Discusión en general en la Comisión de Constitución, Legislación, Justicia y Reglamento del Senado (en adelante, la Comisión de Constitución del Senado)}

Esta intención del legislador, en orden a establecer el acuerdo de unión civil como un acto jurídico de familia, se torna más patente cuando se examina la discusión habida durante la tramitación en general del proyecto de ley en la Comisión de Constitución del Senado, en virtud de las siguientes razones:

2.2.I. Se sostuvo que se está regulando un tipo especial de familia ${ }^{6 \mathrm{I}}$.

2.2.2. Se señaló que este contrato debía dar origen a un nuevo estado civil ${ }^{62}$.

2.2.3. Se dejó constancia de que este contrato debía celebrarse ante un oficial del Registro Civil y debía inscribirse en un registro público ${ }^{63}$.

2.2.4. Se agregó que las controversias a que diera lugar este acuerdo debían ser conocidas por los Tribunales de Familia ${ }^{64}$.

\subsection{Discusión en particular en la Comisión de Constitución del Senado}

2.3.r. El asesor del Ministerio Secretaría General de Gobierno de la época destacó que uno de los elementos esenciales del acuerdo propuesto por el Gobierno era que estaba dirigido a parejas que tuviesen una vida afectiva en común. Esta idea quedó plasmada en el artículo r. ${ }^{\circ}$ del proyecto aprobado por dicha Comi$\operatorname{sión}^{65}$.

2.3.2. A continuación, se discutió la posibilidad que el acuerdo diera origen a un nuevo estado civil. En este punto, el senador Espina sostuvo que era partidario que así fuese, pues, de contrario, se daría una situación extraña, en la que una persona que celebrase este acuerdo seguiría siendo soltera ${ }^{66}$. En el mismo sentido se pronunció la senadora Alvear, quien argumentó su opinión señalando que el único fundamento que existe para impedir que una persona casada pueda

59 Historia de la Ley n. ${ }^{\circ} 20.830$, cit. (n. 9), r6.

60 Historia de la Ley n. ${ }^{\circ} 20.830$, cit. (n. 9), 29.

6r Historia de la Ley n. ${ }^{\circ} 20.830$, cit. (n. 9), I36.

62 Historia de la Ley n. ${ }^{\circ} 20.830$, cit. (n. 9), I 37, I 38 .

63 Historia de la Ley n. ${ }^{\circ} 20.830$, cit. (n. 9), I 37, I38, I 39.

64 Historia de la Ley n. ${ }^{\circ} 20.830$, cit. (n. 9), I 37, I 38 .

65 Historia de la Ley n. ${ }^{\circ} 20.830$, cit. (n. 9), I67, I68.

66 Historia de la Ley n. ${ }^{\circ} 20.830$, cit. (n. 9), I69. 
celebrar un acuerdo de vida en pareja supone aceptar que este genera un estado civil nuevo; agregó, siguiendo la opinión del profesor Somarriva, que el estado civil es el lugar permanente de una persona dentro de la sociedad, que depende principalmente de sus relaciones de familia y que la habilita para ejercer ciertos derechos y contraer ciertas obligaciones civiles; de manera que la celebración de este acuerdo debía dar lugar a un nuevo estado civil ${ }^{67}$. Finalmente, en este punto, la Comisión, por mayoría de votos, se manifestó a favor de que la celebración de este contrato confiriera el estado civil de convivientes legales ${ }^{68}$.

2.3.3. La Comisión de Constitución del Senado también discutió acerca de las inhabilidades para la celebración de este contrato. Por unanimidad de sus miembros se aprobó el impedimento para la celebración de este acuerdo a los ascendientes y descendientes por consanguinidad, a los colaterales por consanguinidad en el segundo grado y a las personas que estén sujetas a vínculo matrimonial o a un acuerdo de vida en pareja vigente ${ }^{69}$, lo que confirma que la intención del legislador fue considerarlo como un acto jurídico de familia.

2.3.4 Por otro lado, la Comisión de Constitución del Senado también se pronunció respecto a la forma de celebración de este acuerdo. Los proyectos presentados por el Ejecutivo y por el senador Allamand establecían que el acuerdo debía celebrarse por escritura pública. Sin embargo, la senadora Alvear propuso que se modificase esta idea y que el acuerdo se celebrase en presencia de un oficial del Registro Civil, el cual debía inscribir este acuerdo en un registro especial a su cargo ${ }^{70}$. El fundamento de esta modificación se encuentra en que el oficial del Registro Civil es el único funcionario que puede dar fe de que no existan incompatibilidades ${ }^{71}$. Si bien esta idea fue, en un principio, rechazada ${ }^{72}$, el Gobierno presentó una indicación para que este acuerdo pudiese celebrarse, no solo ante notario, por medio de una escritura pública, sino también ante un oficial del Registro Civil73; la Comisión aprobó la idea de dejar la opción a los contratantes, en orden a si querían celebrar el acuerdo por escritura pública o ante oficial del Registro Civil74.

2.3.5. También se advierte la intención del legislador de configurar el acuerdo de unión civil como un acto jurídico de familia, cuando, al discutirse acerca de los efectos de este contrato, se aprobó el deber de ayuda mutua y el de solventar los gastos generados por su vida en común, atendidas sus facultades económicas

67 Historia de la Ley n. ${ }^{\circ} 20.830$, cit. (n. 9), I 70.

68 Historia de la Ley n. ${ }^{\circ} 20.830$, cit. (n. 9), I 75.

69 Historia de la Ley n. ${ }^{\circ} 20.830$, cit. (n. 9), I 76.

70 Historia de la Ley n. ${ }^{\circ} 20.830$, cit. (n. 9), I 76, I 77 .

7 I Historia de la Ley n. ${ }^{\circ} 20.830$, cit. (n. 9), I 77 .

72 Historia de la Ley n. ${ }^{\circ} 20.830$, cit. (n. 9), I 77.

73 Historia de la Ley n. ${ }^{\circ} 20.830$, cit. (n. 9), I 78, I 79.

74 Historia de la Ley n. ${ }^{\circ} 20.830$, cit. (n. 9), г 8 o. 
y el régimen patrimonial que exista entre ellos ${ }^{75}$, toda vez que, por una parte, se consagra el deber de ayuda mutua, tal como existe en el matrimonio y, por otra, se hace referencia al régimen patrimonial que exista entre los convivientes civiles, referencia que nos induce a pensar que estamos frente a un acto de familia, pues los actos patrimoniales no dan origen a un régimen patrimonial ${ }^{6}$.

2.3.6. La misma intención queda de manifiesto cuando se examina la discusión habida en torno al tema sucesorio. El texto original del proyecto del Ejecutivo exigía que el acuerdo de vida en pareja hubiese durado, a lo menos, un año para que el conviviente sobreviviente tuviese derechos hereditarios y señalaba que, en la sucesión intestada, concurría con los hijos del causante, recibiendo una porción igual a lo que corresponda a cada hijo; si el causante no hubiere dejado descendencia, le sucederán el contratante sobreviviente y los ascendientes de grado más próximo, debiendo la herencia dividirse en dos partes: la mitad para el contratante y la otra mitad para los ascendientes 77 . En un sentido similar se pronunciaba el proyecto del senador Allamand, con la diferencia que no exigía que el acuerdo hubiese durado un año y, por otro lado, lo designaba como posible asignatario de cuarta de mejoras; en otra disposición agregaba una causal de indignidad para suceder y, finalmente, establecía un derecho de adjudicación preferente similar al que establece la regla ıo. ${ }^{a}$ del artículo I.337 del Código Civil a favor del cónyuge sobreviviente, con la diferencia que no daba la posibilidad de constituir derechos de uso o habitación, gratuitos y vitalicios, en la parte que excediera a su cuota hereditaria ${ }^{78}$. En este punto, la senadora Alvear presentó una indicación tendiente a otorgar al conviviente el carácter de legitimario, concurriendo en la herencia de la misma forma y gozando de los mismos derechos que correspondan al cónyuge sobreviviente, indicación que fue aprobada79.

2.3.7. Siguiendo la misma línea, la Comisión de Constitución del Senado, por unanimidad, aprobó que los convivientes civiles pudiesen ser carga, el uno del otro, tanto en el sistema público como en el sistema privado de salud ${ }^{80}$.

2.3.8. En el mismo sentido, la referida Comisión aprobó que toda inhabilidad, incompatibilidad o prohibición de carácter legal o reglamentario establecida respecto de los cónyuges, se hiciera extensiva, de pleno derecho, a los convivientes civiles ${ }^{8 \mathrm{I}}$, lo que también demuestra que, al asimilarlos a los cónyuges en estas materias, configura al acuerdo de unión civil como un acto jurídico de familia.

Historia de la Ley n. ${ }^{\circ} 20.830$, cit. (n. 9), 200.

80 Historia de la Ley n. ${ }^{\circ} 20.830$, cit. (n. 9), 207.

8 I Historia de la Ley n. ${ }^{\circ} 20.830$, cit. (n. 9), 208. 
2.3.9. Algo similar se produjo cuando se discutió qué tribunales serían competentes para conocer de los asuntos que genere el acuerdo. Los primeros proyectos otorgaban competencia al juez de letras del domicilio de cualquiera de las partes $^{82}$, entendiéndose que se refería a los tribunales civiles ${ }^{8}$. Se propuso una indicación con el objeto de otorgar competencia, para conocer de los asuntos a que diera lugar el acuerdo, a los tribunales de familia ${ }^{84}$. Esta indicación fue respaldada por la senadora Lily Pérez, quien sostuvo que el Mensaje del Ejecutivo señalaba que el proyecto buscaba dar reconocimiento a los distintos tipos de familia; por lo tanto, resultaba coherente que los tribunales competentes fuesen los tribunales de familia ${ }^{8}$. En el mismo sentido, la senadora Alvear señaló expresamente que mediante este contrato se regulan relaciones de familia que van más allá de lo meramente patrimonial ${ }^{86}$. Así también lo consignó el senador Patricio Walker, para quien se está en presencia de una relación afectiva que apunta a persistir en el tiempo, que genera estado civil y una forma de familia respetable, por lo que sus conflictos deben ser resueltos por los tribunales de familia ${ }^{87}$. Esta indicación fue aprobada ${ }^{88}$.

2.3.Io. Siguiendo la misma línea, se presentó una indicación para incorporar una disposición que concediera compensación económica a los convivientes civiles, en términos análogos a los establecidos para los cónyuges y remitiéndose a las mismas reglas que regulan esta institución en la Ley de Matrimonio Civil. Esta indicación fue aprobada ${ }^{8}$.

2.3.I I. Esta comisión también consideró incorporar al conviviente civil como beneficiario en el sistema de pensiones; equipararlo al cónyuge en diversas disposiciones del Código de Procedimiento Civil, del Código Orgánico de Tribunales, de la Ley n. ${ }^{\circ} 20.000$ que sanciona el tráfico ilícito de estupefacientes y sustancias sicotrópicas, de la Ley n. ${ }^{\circ} 20.340$ sobre actos y contratos que se pueden celebrar respecto de viviendas adquiridas con el respaldo de los programas habitacionales estatales, del Código Sanitario, del Código Penal, del Código Procesal Penal, del Código del Trabajo, del Código Civil, y de la Ley n. ${ }^{\circ}$ I 8.3 I 4 que determina conductas terroristas y fija su penalidad ${ }^{\circ}$; lo que demuestra que el acuerdo es un acto jurídico de familia.

Historia de la Ley n. ${ }^{\circ}$ 20.830, cit. (n. 9), 2 Io.

83 Así, por ejemplo, lo entendió la Corte Suprema. Historia de la Ley n. ${ }^{\circ}$ 20.830, cit. (n. 9), 27.

84 Historia de la Ley n. ${ }^{\circ} 20.830$, cit. (n. 9), 2 Iо.

85 Historia de la Ley n. ${ }^{\circ} 20.830$, cit. (n. 9), 2 Iо.

86 Historia de la Ley n. ${ }^{\circ} 20.830$, cit. (n. 9), 2 Iо, 2 I I.

87 Historia de la Ley n. ${ }^{\circ} 20.83$ o, cit. (n. 9), 2 I I.

88 Historia de la Ley n. ${ }^{\circ} 20.830$, cit. (n. 9), 2 I I.

89 Historia de la Ley n. $^{\circ} 20.830$, cit. (n. 9), 2 I I, 2 I 2.

90 Historia de la Ley n. ${ }^{\circ} 20.830$, cit. (n. 9), 2 I 2 a 22 I. 


\subsection{Discusión en general en la sala del Senado}

De lo expuesto por los senadores en la discusión en general que tuvo lugar en la sala del Senado, se desprende que su intención fue configurar un acto jurídico de familia:

2.4. I. Se dejó constancia de que este contrato permitirá prestarse ayuda mutua, compartir una vida en común y resolver distintas cuestiones relacionadas con la administración de sus bienes y con materias sucesorias ${ }^{91}$, agregándose que los contratantes deben tener la posibilidad de optar por distintos regímenes patrimoniales ${ }^{22}$.

2.4.2. Se sostuvo que el acuerdo trataba de regular verdaderas relaciones de familia y los efectos jurídicos derivados de su vida afectiva en común; que se buscaba que quienes celebraran el acuerdo fueran reconocidos como una forma de familia. En este sentido, el gobierno de la época señaló que el Ejecutivo buscaba reconocer y dar dignidad a todas las familias, pues existen muchos tipos de familia que se construyen en torno a la convivencia y a un sentimiento, aunque no estén ligadas por una unión formal93. El senador Cantero agregó que se trata de fortalecer la familia, ya que esta se halla ligada a las relaciones que generan las personas 94 ; Bianchi sostuvo que se trata de regular una relación entre dos personas en la que hay amor, afectos y una convivencia ${ }^{95}$, es decir, se trata de una relación de familia; Lagos entendió que se trata de regular una relación de familia, que surge del afecto o del amor ${ }^{6}$; Rossi entendió que se busca regular un tipo de familia, en la que sus integrantes se prodigan afecto, se proyectan hacia el futuro, hacen vida en conjunto, en comunidad y viven bajo el mismo techo ${ }^{97}$; Espina, para quien lo que está haciendo el Estado es regular una relación que surge del cariño y del amor, y se trata de construir una familia a partir de una relación que nace del sentimiento ${ }^{98}$; Lily Pérez, quien además señaló que se trata de regular un tipo de relación que surge del amor, de ahí que, en su concepto, se trata de reconocer los distintos tipos de familia que existen ${ }^{99}$; Letelier, quien sostuvo que regula relaciones afectivas, agregando que, en su concepto, la relación afectiva es un derecho humano básico, insistiendo en que se trata de regular una

9I Historia de la Ley n. ${ }^{\circ} 20.830$, cit. (n. 9), 234.

92 Historia de la Ley n. ${ }^{\circ} 20.830$, cit. (n. 9), 242, 243, 25 I, 282.

93 Historia de la Ley n. ${ }^{\circ} 20.830$, cit. (n. 9), 235, 237, 238, 239, 256,284 .

94 Historia de la Ley n. ${ }^{\circ} 20.830$, cit. (n. 9), 259.

95 Historia de la Ley n. ${ }^{\circ} 20.830$, cit. (n. 9), 26 I.

96 Historia de la Ley n. ${ }^{\circ} 20.830$, cit. (n. 9), 274.

97 Historia de la Ley n. ${ }^{\circ} 20.830$, cit. (n. 9), 244.

$9^{8}$ Historia de la Ley n. ${ }^{\circ} 20.830$, cit. (n. 9), 254.

99 Historia de la Ley n. ${ }^{\circ} 20.830$, cit. (n. 9), $25^{8}$. 
relación de familia ${ }^{\mathrm{IOO}}$; Muñoz Aburto, quien entendió que debía regularse la vida afectiva y cuestiones de orden doméstico, de la vida cotidiana, como la voluntad para la donación de órganos, el ingreso en calidad de familiar a hospitales y las decisiones que tienen que ver con la sepultación ${ }^{\mathrm{Ior}}$; Quintana, que agregó que el proyecto busca regular derechos sucesorios, previsionales, apoyo mutuo y, en general, la vida en común donde hay afecto, cariño, bondad y todos los atributos que se pueden imaginar en una familia que ha evolucionado con el correr de los años $^{102}$, y Pizarro, quien sostuvo que se trata de reconocer los diferentes tipos de familia y de regular uno de ellos ${ }^{\text {I03 }}$.

2.4.3. Como consecuencia de lo anterior, se entendió que este contrato debía generar un estado civil nuevo ${ }^{\text {104. }}$

2.4.4. Por lo mismo, los conflictos que surjan entre los convivientes civiles deberían ser resueltos por los tribunales de familia ${ }^{\mathrm{I0}}$.

2.4.5. Se consignaron como efectos de este acuerdo que los contratantes se deberían ayuda mutua y que estarían obligados a solventar los gastos generados por su vida en común, conforme a sus facultades económicas y al régimen patrimonial existente entre ellos ${ }^{\mathrm{I} 06}$.

2.4.6. A los contratantes se les debiera considerar como legitimarios, concurriendo en la herencia de la misma forma y con los mismos derechos que corresponden al cónyuge sobreviviente ${ }^{107}$.

2.4.7. A raíz de todo lo anterior, se presentó una indicación, en orden a que este acuerdo pudiese celebrarse solamente ante oficial del Registro Civil ${ }^{\text {I08 }}$. El senador Hernán Larraín se manifestó de acuerdo, pero con la salvedad que debía existir la alternativa entre celebrarlo por escritura pública o ante oficial del Registro Civil ${ }^{109}$.

A partir de todo lo señalado, la idea de legislar fue aprobada en la sala del Senado por 28 votos a favor, 6 en contra y 2 abstenciones $^{\text {IIO }}$.

Ioo Historia de la Ley n. ${ }^{\circ} 20.830$, cit. (n. 9), 265 .

IOI Historia de la Ley n. ${ }^{\circ} 20.830$, cit. (n. 9), 277.

IO2 Historia de la Ley n. ${ }^{\circ} 20.830$, cit. (n. 9), 287.

I03 Historia de la Ley n. ${ }^{\circ} 20.83$, cit. (n. 9), 282.

I04 Historia de la Ley n. ${ }^{\circ} 20.830$, cit. (n. 9), 235, 242, 243, 245, 254, 265, 277, 282.

Io5 Historia de la Ley n. ${ }^{\circ} 20.83$ o, cit. (n. 9), $235,243,245,258,282$.

Io6 Historia de la Ley n. ${ }^{\circ} 20.830$, cit. (n. 9), $235,265$.

I07 Historia de la Ley n. ${ }^{\circ} 20.830$, cit. (n. 9), 235, 243, 245 .

Io8 Historia de la Ley n. ${ }^{\circ} 20.830$, cit. (n. 9), 236, 242, 244, $263,264,282$.

Io9 Historia de la Ley n. ${ }^{\circ} 20.830$, cit. (n. 9), 254.

I Io Historia de la Ley n. ${ }^{\circ} 20.830$, cit. (n. 9), 289. 


\subsection{Indicaciones formuladas durante la discusión en general en el Senado}

En el Senado se presentaron r6o indicaciones; de ellas, las que fueron aprobadas dan cuenta de la intención del legislador de configurar el acuerdo de vida en pareja como un acto jurídico de familia, según se verá a continuación:

2.5.I. Se propuso que, en el inciso primero del artículo primero, al definirse el acuerdo de vida en pareja, se agregase la frase "de carácter estable y permanente", lo que da a entender que se busca regular un tipo de familia ${ }^{\text {II }}$.

2.5.2. Se propuso sustituir el inciso tercero del artículo primero, por el siguiente: "La celebración del presente contrato conferirá a los contrayentes el estado civil de convivientes legales, y dará lugar al parentesco por afinidad en los términos del artículo 3 I del Código Civil” I²; para justificar su voto favorable a esta indicación, el senador Espina señaló que, de conformidad con la definición de estado civil establecida en el artículo 304 del Código Civil ${ }^{113}$, de la celebración de este contrato surgen obligaciones y derechos y, por tanto, su celebración debe generar un estado civil nuevo ${ }^{\mathrm{II}}$. Finalmente, el texto aprobado por la Comisión fue el siguiente: "Entre un conviviente civil y los consanguíneos de la persona a la que está unida por un acuerdo de vida en pareja existirá, mientras éste se encuentre vigente, parentesco por afinidad. La línea y el grado de afinidad de una persona con un consanguíneo de su conviviente civil, se califica por la línea o grado de consanguinidad de dicho conviviente civil" I 5 .

2.5.3. Se propuso sustituir el inciso tercero del artículo primero, por el siguiente: "El acuerdo de vida en común no podrá sujetarse a plazo, condición, modo ni gravamen alguno" I'6.

2.5.4. Se propuso incorporar, como inciso cuarto del artículo primero, el siguiente: "Entre una persona que ha celebrado este contrato y los consanguíneos de su conviviente existe parentesco por afinidad" ${ }^{17}$. La Comisión acordó precisar que en el inciso $2 .^{\circ}$ del artículo r..$^{\circ}$ debía agregarse que las partes de este contrato serán considerados parientes para los efectos previstos en el artículo $4^{2}$ del Código Civil y en el inciso $3^{\circ}$ de esta disposición debía agregarse que el término de este acuerdo restituirá a los contrayentes el estado civil que tenían antes de celebrar este contrato, salvo que contraigan matrimonio ${ }^{118}$.

I I I Historia de la Ley n. ${ }^{\circ} 20.830$, cit. (n. 9), 332, 392.

I 2 Historia de la Ley n. ${ }^{\circ} 20.830$, cit. (n. 9), 333, 392.

I 3 Art. 304 C. C.: "El estado civil es la calidad de un individuo, en cuanto le habilita para ejercer ciertos derechos o contraer ciertas obligaciones civiles".

I 4 Historia de la Ley n. ${ }^{\circ} 20.830$, cit. (n. 9), 425.

I 5 Historia de la Ley n. ${ }^{\circ} 20.830$, cit. (n. 9), 427, 429 .

I 6 Historia de la Ley n. ${ }^{\circ} 20.830$, cit. (n. 9), 333, 392.

I 7 Historia de la Ley n. ${ }^{\circ} 20.830$, cit. (n. 9), 333, 392.

I 8 Historia de la Ley n. ${ }^{\circ} 20.830$, cit. (n. 9), 429. 
2.5.5. Se propuso suprimir el artículo $3 .^{\circ}$, que establecía que el contrato debía celebrarse por escritura pública ${ }^{19}$. Esta indicación fue apoyada por el Ejecutivo, manifestando que este contrato debería celebrarse solamente ante el oficial del Registro Civil, dado que así se realzaría el sentido del mismo y se evitaría la producción de fraudes, debido al sistema de registro único que llevaría este servicio $^{\mathrm{I} 2 \mathrm{O}}$, y por los senadores De Urresti, quien sostuvo que la celebración ante el oficial del Registro Civil da publicidad y acceso expedito e igualitario, a lo largo de todo el territorio nacional, a quienes deseen celebrarlo ${ }^{\text {I2 I }}$, y Espina, quien agregó que no era conveniente que el contrato se celebrase ante notario, pues está creando un estado civili22_-123.

2.5.6. Se propuso reemplazar el artículo $4 .^{\circ}$, por el siguiente: "En el acto de celebración, el Oficial del Registro Civil levantará acta de todo lo obrado, la que será firmada por él y por los contratantes si quieren y pudieren hacerlo. De manera previa, los contratantes deberán declarar expresamente no encontrarse ligados por vínculo matrimonial o un acuerdo de vida en pareja vigente.

Luego de la celebración del acto, el oficial del Registro Civil procederá a hacer la inscripción en los libros del Registro Civil en la forma prescrita en el Reglamento"I24.

Por su parte, la senadora Rincón ${ }^{\mathrm{I} 25}$ propuso sustituir el inciso primero del artículo $4 .^{\circ}$, por el siguiente: " $\mathrm{El}$ acuerdo de vida en pareja deberá ser celebrado en el Registro Civil, ante el respectivo oficial, quien levantará acta de todo lo obrado, la que será firmada por él y por los contratantes. El oficial deberá inscribir el acuerdo de vida en pareja inmediatamente luego de celebrado el contrato, en un registro especial que llevará el Servicio de Registro Civil e Identificación al efecto".

Finalmente, la comisión acordó cambiar la redacción del inciso $2 .^{\circ}$ por el siguiente: "En este acto, los contrayentes deberán declarar por escrito, oralmente, o por lenguaje de señas acerca del hecho de no encontrarse ligados por vínculo

I 9 Historia de la Ley n. ${ }^{\circ} 20.830$, cit. (n. 9), 334, 392.

I 20 Historia de la Ley n. ${ }^{\circ} 20.830$, cit. (n. 9), 432.

I 2 I Historia de la Ley n. ${ }^{\circ} 20.830$, cit. (n. 9), 433.

I 22 Historia de la Ley n. ${ }^{\circ} 20.830$, cit. (n. 9), 433.

I $23 \mathrm{El}$ asesor jurídico del senador Espina expresamente sostuvo que, "en sus inicios, el acuerdo de vida en pareja era de naturaleza mixta, es decir, por una parte patrimonial y por la otra, como un contrato perteneciente al Derecho de Familia, expuso que al aprobarse que genere estado civil para quienes lo celebren pasa a transformarse en una institución del Derecho de Familia y, en este ámbito, la autonomía de la voluntad se encuentra absolutamente restringida". Historia de la Ley n. ${ }^{\circ} 20.830$, cit. (n. 9), 433.

I 24 Historia de la Ley n. ${ }^{\circ} 20.830$, cit. (n. 9), 336, 392.

I 25 Historia de la Ley n. ${ }^{\circ} 20.830$, cit. (n. 9), 337, 392. 
matrimonial o acuerdo de vida en pareja vigente" ${ }^{226}$, lo que demuestra su carácter exclusivo, propio de los actos de familia.

2.5.7. Dado que se excluyó la posibilidad de celebrar el acuerdo de unión civil por escritura pública, se propuso modificar el artículo $5 .^{\circ}$, agregando la frase "El acta levantada por el oficial del Registro Civil a que se refiere el artículo anterior se inscribirá" antes de la frase "en un registro especial que llevará el Servicio de Registro Civil e Identificación”; es decir, eliminó toda referencia a la inscripción de la escritura pública donde constase la celebración de este acuerdo. Por otro lado, propuso suprimir la frase "El plazo para solicitar su inscripción será de diez días hábiles contado desde su otorgamiento, a petición de cualquiera de los contratantes", la cual ya no se justificaba ${ }^{127}$.

2.5.8. Como consecuencia de lo anterior, se propuso suprimir del artículo 6. ${ }^{\circ}$, letra d), la frase "dependiendo de la forma en que se haya celebrado el acuerdo de vida en pareja ${ }^{\mathrm{I28}}{ }^{\mathrm{I} 29}$.

2.5.9. Se propuso eliminar del epígrafe del Título in de la ley, la palabra "patrimoniales" ${ }_{30}{ }_{-1}{ }^{1}$ I.

2.5.ro. Se propuso incorporar un nuevo inciso segundo al artículo 9, del siguiente tenor: "El conviviente civil será también posible asignatario de la cuarta de mejoras" 132 - 333 .

2.5.I I. Se propuso incorporar un nuevo artículo del siguiente tenor: "El miembro de la pareja legal sobreviviente tendrá derecho a que su cuota hereditaria se entere con preferencia mediante la adjudicación en favor suyo de la propiedad del inmueble en que resida y que sea o haya sido la vivienda principal de la familia, así como del mobiliario que lo guarnece, siempre que ellos formen parte del patrimonio del difunto.

Si el valor total de dichos bienes excede la cuota hereditaria del miembro de la pareja legal sobreviviente, este podrá pedir que sobre las cosas que no le sean

I 26 Historia de la Ley n. ${ }^{\circ} 20.83$ o, cit. (n. 9), 437.

I 27 Historia de la Ley n. ${ }^{\circ} 20.830$, cit. (n. 9), 338,392 .

I 28 Historia de la Ley n. ${ }^{\circ} 20.83$ o, cit. (n. 9), 342, 392.

I29 Dicha disposición se refiere a las formas de terminación del acuerdo y, en particular, al mutuo acuerdo de los contratantes. Como se había establecido que solamente podría celebrarse ante Oficial del Registro Civil, no resultaba coherente que esta disposición hiciera referencia a diversas formas de celebración, como sí lo permitía el proyecto original.

I 30 Historia de la Ley n. ${ }^{\circ} 20.83$ o, cit. (n. 9), 346, 392.

I3 I Originalmente, el epígrafe del Título in señalaba: "De los efectos patrimoniales del acuerdo de vida en pareja"; al eliminarse la expresión "patrimoniales", se da a entender que la intención del legislador fue que este contrato no solo produjese efectos patrimoniales, lo que confirma que se trata de un acto jurídico de familia.

I 32 Historia de la Ley n. ${ }^{\circ} 20.83$ O, cit. (n. 9), 35 I, 392.

I33 Esta disposición regulaba, originalmente, los derechos hereditarios del conviviente civil sobreviviente. 
adjudicadas en propiedad, se constituya en su favor derecho de habitación y de uso, según la naturaleza de las cosas, con carácter de gratuitos y vitalicios.

El derecho de habitación no será oponible a terceros de buena fe mientras no se inscriba la resolución que lo constituye en el Registro del Conservador de Bienes Raíces. En todo lo no previsto, el uso y la habitación se regirán por lo dispuesto en el Título x del Libro II.

El derecho a la adjudicación preferente de que habla esta regla no puede transferirse ni transmitirse" 34 .

$\mathrm{Al}$ discutirse esta indicación en la Comisión de Constitución del Senado, se decidió aprobarla, pero modificando su texto, el cual quedó del siguiente tenor: "El conviviente civil sobreviviente, tendrá también el derecho de adjudicación

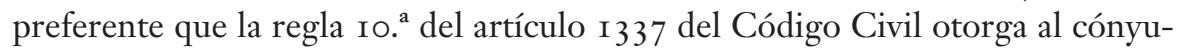
ge sobreviviente. Tendrá, asimismo, en iguales condiciones que las prescritas en esta regla, los derechos de habitación y de uso, que la misma concede al cónyuge sobreviviente para el caso en que el valor total del inmueble en que resida y que sea o haya sido la vivienda principal de la familia, así como del mobiliario que lo guarnece, excedan su cuota hereditaria" ${ }^{35}$.

2.5.I2. Se propuso sustituir el artículo I4, por el siguiente: "No podrá prometerse la celebración de un acuerdo de vida en común" ${ }^{36}$.

2.5.I3. Se propuso reemplazar el artículo I 7, por el siguiente: "Si como consecuencia de haberse dedicado al cuidado de los hijos o a las labores propias del hogar común, uno de los convivientes no pudo desarrollar una actividad remunerada o lucrativa durante la vigencia del acuerdo de vida en pareja, o lo hizo en menor medida de lo que podía y quería, tendrá derecho a que, si la terminación se produce por alguna de las causales contempladas en las letras d), e) o f) del artículo 6 de esta ley, se le compense el menoscabo económico sufrido por esta causa"; es decir, incorporó la compensación económica para el conviviente civil más débil ${ }^{137}$.

2.5.I4. Se propuso incorporar el siguiente artículo nuevo: "El conviviente civil será llamado en primer lugar a la curaduría del otro miembro de la pareja que se encuentre demente, conforme a lo dispuesto en el número I del artículo 462 del Código Civil.

Ningún conviviente civil podrá ser curador del otro declarado disipador”.

Finalmente, se aprobó esta idea, pero modificándose su redacción, la cual quedó del siguiente tenor: "Lo dispuesto en el artículo 450 y en el número r. ${ }^{\circ}$ del artículo 462, ambos del Código Civil, será aplicable a los convivientes civiles" ${ }^{1}{ }^{8}$.

I 34 Historia de la Ley n. ${ }^{\circ} 20.830$, cit. (n. 9), 352, 392.

I 35 Historia de la Ley n. ${ }^{\circ} 20.830$, cit. (n. 9), 487 .

I 36 Historia de la Ley n. ${ }^{\circ} 20.830$, cit. (n. 9), 355, 392.

I 37 Historia de la Ley n. ${ }^{\circ} 20.830$, cit. (n. 9), 356, 392.

I 38 Historia de la Ley n. ${ }^{\circ} 20.830$, cit. (n. 9), 496, 497 . 
2.5.I 5. El Ejecutivo propuso intercalar un nuevo artículo 2 I que modificase el Estatuto Administrativo, en los siguientes sentidos: por una parte, permitiendo que, en caso de fallecimiento de un funcionario público, su conviviente civil sobreviviente tuviese derecho a percibir la remuneración que a aquel correspondiere, hasta el último día del mes en que hubiese ocurrido el deceso, y, por otra, que, en igual caso, el conviviente civil tendrá derecho a percibir el desahucio que habría correspondido al funcionario si se hubiere retirado a la fecha del fallecimiento. El mismo derecho se consagró para quienes estuviesen sujetos al Estatuto Administrativo para Funcionarios Municipales ${ }^{\mathrm{I}} 39$.

Estas indicaciones fueron aprobadas con modificaciones, señalándose expresamente que la intención de los legisladores era la de equiparar al cónyuge sobreviviente con el contratante del acuerdo de vida en pareja ${ }^{\mathrm{I}}{ }^{\circ}$.

2.5.I6. El Ejecutivo propuso agregar un artículo 33 nuevo, que introdujese varias modificaciones al Código del Trabajo, incorporando al conviviente civil en todos los casos en que se confiere algún derecho al cónyuge ${ }^{\mathrm{I} 4 \mathrm{I}}$.

2.5.I 7. Se propuso agregar un artículo 32 nuevo, del siguiente tenor: "Sin perjuicio de lo anterior, el tribunal competente podrá entregar el cuidado personal del niño al conviviente civil o cónyuge no padre o madre, siempre que haya contribuido significativamente a su crianza y educación"; ello, a propósito de la reforma al artículo 226 del Código Civil en materia de cuidado personal ${ }^{142}$.

2.5.I8. Se propuso modificar el n. ${ }^{\circ}$ I del artículo 5. ${ }^{\circ}$ de la Ley n. ${ }^{\circ}$ i 9.947 sobre matrimonio civil, incorporando como impedimento dirimente para el matrimonio: "Los que se hallaren ligados por vínculo matrimonial no disuelto o mantuvieren con terceros un acuerdo de vida en pareja vigente". Ello demuestra la incompatibilidad que existe entre matrimonio y acuerdo de unión civil, esto es, una persona no puede estar unida simultáneamente por matrimonio y acuerdo de unión civil, y esta incompatibilidad se justifica solo en la medida que se considere al acuerdo de unión civil como un acto jurídico de familia ${ }^{\mathrm{I} 43^{-1}}{ }^{-14}$.

I39 Historia de la Ley n. ${ }^{\circ} 20.830$, cit. (n. 9), $367,368,392$.

I40 Historia de la Ley n. ${ }^{\circ} 20.830$, cit. (n. 9), 5 I 7,5 I 9 .

I4I Historia de la Ley n. ${ }^{\circ} 20.830$, cit. (n. 9), 369, 370, 392.

I42 Historia de la Ley n. ${ }^{\circ} 20.830$, cit. (n. 9), 37 I 392.

I43 Historia de la Ley n. ${ }^{\circ} 20.830$, cit. (n. 9), 376, 392.

I 44 Cabe tener presente que, originalmente, el proyecto señalaba que el acuerdo de vida en pareja terminaba si uno de los contratantes contraía matrimonio con un tercero; sin embargo, ello cambió y, en el texto aprobado por la Comisión de Constitución del Senado, se estableció que un acuerdo de vida en pareja vigente constituye un impedimento dirimente para el matrimonio. Historia de la Ley n. ${ }^{\circ} 20.830$, cit. (n. 9), 537. 


\subsection{Discusión en particular en la sala del Senado}

En la discusión en particular que se dio en la sala del Senado, también se plasmó esta idea de considerar al acuerdo de unión civil como un acto jurídico de familia:

2.6. I. Se sostuvo que el proyecto se refiere a afectos, hijos y otros aspectos que dicen relación con la dignidad de la persona ${ }^{\mathrm{I} 45}$. También se señaló la posibilidad de reconocer opciones diversas de vida afectiva ${ }^{\mathrm{4}}{ }^{6}$, y que se trataba de regular una relación estable y basada en el amor ${ }^{\mathrm{I} 47}$.

2.6.2. Se consagran aspectos afectivos, como el cuidado de la pareja y la solidaridad mutua ${ }^{\mathrm{I}}{ }^{8}$.

2.6.3. El hecho que las inhabilidades y prohibiciones fuesen las mismas que rigen para los cónyuges ${ }^{\mathrm{I}} 49$ demuestra que estamos frente a un acto jurídico que comparte la misma naturaleza que el matrimonio, esto es, se trata de un acto jurídico de familia.

2.6.4. En definitiva, se ha regulado un tipo de relación de familia ${ }^{15}$. Además, se remarcó que el propósito de este contrato es regular los efectos jurídicos derivados de su vida afectiva en común, de carácter estable y permanente ${ }^{\mathrm{I} 5 \mathrm{I}}$.

2.6.5. Los conflictos serán de conocimiento de los tribunales de familia ${ }^{152}$.

2.6.6. Los contratantes adquieren un nuevo estado civil ${ }^{153}{ }^{1}{ }^{154}$.

2.6.7. Se planteó que el parentesco por afinidad se regula de manera similar al régimen que existe para los cónyuges ${ }^{\mathrm{I} 55}$.

2.6.8. Se señaló que se contempla una compensación económica para la parte más débil en caso de nulidad, similar a la del divorcio tratándose del matrimonio $^{156}$.

2.6.9. En materia de filiación, se establece que, cuando fallece uno de los convivientes padre o madre de un hijo biológico criado con la pareja, el juez podrá entregar el cuidado del niño o niña al conviviente civil sobreviviente, con-

I 45 Historia de la Ley n. ${ }^{\circ} 20.830$, cit. (n. 9), 637, 65 I , 665 .

I46 Historia de la Ley n. ${ }^{\circ} 20.830$, cit. (n. 9), 643 .

I47 Historia de la Ley n. ${ }^{\circ} 20.830$, cit. (n. 9), 646.

I 48 Historia de la Ley n. ${ }^{\circ} 20.830$, cit. (n. 9), 637, 64I.

I49 Historia de la Ley n. ${ }^{\circ} 20.830$, cit. (n. 9), 637 .

I 5 O Historia de la Ley n. ${ }^{\circ} 20.83$ o, cit. (n. 9), 637, 654, 663 $, 665,668$.

I 5 I Historia de la Ley n. ${ }^{\circ} 20.830$, cit. (n. 9), 672.

I 52 Historia de la Ley n. ${ }^{\circ} 20.830$, cit. (n. 9), 637, 648, 653 .

I $53 \mathrm{El}$ senador Araya agregó que "uno puede colegir que al establecerse estado civil se están aplicando normas de orden público de carácter familiar”. Historia de la Ley n. ${ }^{\circ} 20.830$, cit. (n. 9), 64I.

I 54 Historia de la Ley n. ${ }^{\circ} 20.830$, cit. (n. 9), 637, 639, 641, 647, 650, 652, 672.

I 55 Historia de la Ley n. ${ }^{\circ} 20.830$, cit. (n. 9), 637 .

I 56 Historia de la Ley n. ${ }^{\circ} 20.83$ o, cit. (n. 9), 638 . 
siderando el bien superior del menor ${ }^{157}$. El senador Rossi agregó que le parecía de una lógica absoluta que en esta materia se permitiese abrir una ventana y consignar la posibilidad de que el juez, entre todas las alternativas para entregar el cuidado del menor, considere, asimismo, al conviviente civil sobreviviente ${ }^{15}$. El senador Ignacio Walker sostuvo que ello era sensato ${ }^{159}$, y el senador Araya estuvo de acuerdo con que corresponda al juez valorar la situación puntual que se le presente y, atendiendo al interés superior del menor, pueda otorgar la tuición al conviviente civil que no es progenitor biológico, en la medida que haya contribuido significativamente a su educación, a solventar sus gastos y sea parte integrante de su núcleo familiar ${ }^{\mathrm{I} 60}$.

2.6. Io. El acuerdo se puede celebrar solamente ante oficial del Registro Civil $^{16 \mathrm{I}}$.

2.6. I I. Se reconoce al conviviente civil como carga, particularmente para efectos del sistema de salud, agregándose que el proyecto homologa muchos derechos del conviviente civil sobreviviente a los del cónyuge para efectos laborales, de pensiones de sobrevivencia y de derechos hereditarios ${ }^{162}$.

2.6. I 2. Se sostuvo que los convivientes civiles serán considerados parientes para los efectos previstos en el artículo 42 del Código Civil ${ }^{163}$.

2.6. I 3. Se señaló que la figura del conviviente civil se asimila a la del cónyuge para efectos de los derechos hereditarios ${ }^{164}$.

2.6.I4. Se consignó que se regula un régimen patrimonial para los convivientes civiles ${ }^{165}$, cuestión propia de un estatuto familiar.

\subsection{Discusión en general babida en la Comisión de Constitución, Legislación y Fusticia de la Cámara de Diputados}

2.7.I. Se sostuvo que el proyecto busca regular las diversas formas de familia; las relaciones de familia y los derechos que emanan de ella deben considerarse parte de los derechos sociales ${ }^{\mathrm{I} 66}$.

I 57 Historia de la Ley n. ${ }^{\circ} 20.830$, cit. (n. 9), 653 .

I 58 Historia de la Ley n. ${ }^{\circ} 20.830$, cit. (n. 9), 638, 709 .

I 59 Historia de la Ley n. ${ }^{\circ} 20.830$, cit. (n. 9), 640.

I60 Historia de la Ley n. ${ }^{\circ} 20.830$, cit. (n. 9), 642.

I6I Historia de la Ley n. ${ }^{\circ} 20.830$, cit. (n. 9), 640, 641, 647, 65 I, 652, $672,673$.

I62 Historia de la Ley n. ${ }^{\circ} 20.830$, cit. (n. 9), 653 .

I63 Historia de la Ley n. ${ }^{\circ} 20.830$, cit. (n. 9), 673 .

i64 Historia de la Ley n. ${ }^{\circ} 20.830$, cit. (n. 9), $673,674$.

I65 Historia de la Ley n. ${ }^{\circ} 20.830$, cit. (n. 9), 737.

I66 Historia de la Ley n. ${ }^{\circ} 20.830$, cit. (n. 9), 77 I, 834 . 
2.7.2. Se dejó constancia de que el acuerdo de unión civil daba origen a un nuevo estado civil ${ }^{167}$.

2.7.3. Se sostuvo que el acuerdo de unión civil permite la declaración de bien familiar, señalándose que esta institución tiene por finalidad proteger el bien raíz donde reside la familia ${ }^{\mathrm{I} 68}$.

2.7.4. Se presentó una indicación para dejar claro que los asuntos que se susciten entre los convivientes civiles, derivados del acuerdo y su terminación, serán resueltos por el juez con competencia en materias de familia ${ }^{169}$.

2.7.5. Se discutió la modificación al artículo 226 del Código Civil, en orden a que el juez de familia pudiese confiar el cuidado personal de un hijo al conviviente civil de su padre o madre biológico. En este sentido, se sostuvo que existía la necesidad de enviar una señal, en orden a reconocer expresamente al conviviente civil en esta materia ${ }^{170}$.

\subsection{Discusión en la sala de la Cámara de Diputados}

2.8. I. Se dejó constancia de que el acuerdo se celebra ante oficial del Registro Civili7r.

2.8.2. Se enfatizó que la celebración del acuerdo da origen a un nuevo estado civil $^{172}$.

2.8.3. Se señaló que los conflictos a que dé origen este acuerdo serán resueltos por los tribunales de familia ${ }^{173}$.

2.8.4. Se agregó que el proyecto hace parte del Derecho de Familia a estas uniones ${ }^{174}$. Se trata de reconocer y proteger diversas clases de familia ${ }^{\mathrm{I}} 75$.

2.8.5. Se sostuvo que la celebración de este acuerdo crea una relación de parentesco entre uno de los convivientes y los consanguíneos del otro ${ }^{176}$.

2.8.6. Se agregó que se reconoce al conviviente civil como carga para los efectos del sistema de salud ${ }^{177}$. Además, hubo una referencia, en general, a los derechos previsionales del conviviente civil $^{17^{8}}$.

I67 Historia de la Ley n. ${ }^{\circ} 20.830$, cit. (n. 9), 840.

I68 Historia de la Ley n. ${ }^{\circ} 20.830$, cit. (n. 9), 860.

I69 Historia de la Ley n. ${ }^{\circ} 20.830$, cit. (n. 9), 868.

I 70 Historia de la Ley n. ${ }^{\circ} 20.830$, cit. (n. 9), 890, 892.

I 7 I Historia de la Ley n. ${ }^{\circ}$ 20.830, cit. (n. 9), 948, 953, 955, 964, 974, 975, 987.

I 72 Historia de la Ley n. ${ }^{\circ}$ 20.830, cit. (n. 9), 948, 950, 953, 959, 974, 975 .

I 73 Historia de la Ley n. ${ }^{\circ} 20.830$, cit. (n. 9), 948.

I 74 Historia de la Ley n. ${ }^{\circ} 20.830$, cit. (n. 9), 948.

I 75 Historia de la Ley n. ${ }^{\circ}$ 20.830, cit. (n. 9), 955, 957, 963, 967, 970, 97 I, 972 , 974, 976, 977, 979.

i 76 Historia de la Ley n. ${ }^{\circ} 20.830$, cit. (n. 9), 948, 950, 953.

I 77 Historia de la Ley n. ${ }^{\circ}$ 20.830, cit. (n. 9), 948, 949, 953, 974, 982.

I 78 Historia de la Ley n. ${ }^{\circ} 20.830$, cit. (n. 9), 959. 
2.8.7. Se dejó constancia de que este proyecto busca mejorar las condiciones jurídicas y sociales de dos personas que se aman, viven bajo un mismo techo y conforman una familia ${ }^{179}$. Además se reconoció que se trata de regular una unión que nace de la afectividad ${ }^{180}$. Por otro lado, se sostuvo que el proyecto se hace cargo de una realidad social, cultural y afectiva de personas que deciden vivir en común porque hay amor ${ }^{\mathrm{I} 8 \mathrm{I}}$; que se busca regular los efectos jurídicos de su vida afectiva en común ${ }^{182}$, y que se regula un tipo de familia en la que manda el $\operatorname{amor}^{18}$.

2.8.8. También se afirmó que los convivientes civiles serán considerados parientes para los efectos previstos en el artículo 42 del Código Civil ${ }^{184}$.

2.8.9. Se agregó que se homologan los derechos del conviviente civil sobreviviente a los del cónyuge para efectos laborales, por ejemplo, para tener derecho a un permiso para ausentarse del trabajo en caso de fallecimiento del otro conviviente, el derecho a percibir la última remuneración del conviviente fallecido, el derecho a recibir el desahucio del conviviente fallecido, y el derecho a ser beneficiario de la pensión de sobrevivencia ${ }^{185}$.

2.8. Io. También se refirió a la posibilidad de declaración de bien familiar respecto de la casa donde habita la familia ${ }^{186}$.

2.8. I I. Se agregó que la paternidad de los hijos se determina aplicando la presunción de paternidad ${ }^{187}$.

\subsection{Informe de la Comisión Mixta}

2.9. I. Propuso que la definición de acuerdo de unión civil expresamente dijese que se trata de un contrato que celebran dos personas que comparten un ho$\operatorname{gar}^{188}$.

2.9.2. Se dio una nueva redacción al artículo i 6 del proyecto, señalando que el conviviente civil será heredero intestado y legitimario del otro; que concurrirá en su sucesión de la misma forma y gozará de los mismos derechos que corres-

I79 Historia de la Ley n. ${ }^{\circ} 20.830$, cit. (n. 9), 949.

I80 Historia de la Ley n. ${ }^{\circ} 20.830$, cit. (n. 9), 965.

I8 1 Historia de la Ley n. ${ }^{\circ} 20.830$, cit. (n. 9), 974.

I82 Historia de la Ley n. ${ }^{\circ} 20.830$, cit. (n. 9), 975.

I 83 Historia de la Ley n. ${ }^{\circ} 20.830$, cit. (n. 9), 977.

I 84 Historia de la Ley n. ${ }^{\circ} 20.83$ o, cit. (n. 9), 953 .

I85 Historia de la Ley n. ${ }^{\circ} 20.830$, cit. (n. 9), 957, 974.

I 86 Historia de la Ley n. ${ }^{\circ} 20.830$, cit. (n. 9), 959.

I87 Historia de la Ley n. ${ }^{\circ} 20.830$, cit. (n. 9), 959 .

I 88 Historia de la Ley n. ${ }^{\circ} 20.830$, cit. (n. 9), r.044. 
pondan al cónyuge sobreviviente, y que podrá ser asignatario de la cuarta de mejoras $^{189}$.

2.9.3. Se dio una nueva redacción al artículo 22, el cual expresa que deberá conocer de los asuntos a que se refiere el artículo 8..$^{\circ}$ de la Ley n. ${ }^{\circ}$ i 9.968 (que crea los Tribunales de Familia), que se promuevan entre los convivientes civiles, el juez con competencia en materias de familia' ${ }^{190}$.

Estas proposiciones fueron aprobadas por ambas cámaras ${ }^{\mathrm{I} 9 \mathrm{I}}$.

\section{Conclusiones}

A partir del análisis hecho a través de este trabajo, es posible concluir que, aunque el artículo primero de la Ley n. ${ }^{\circ} 20.830$ define al acuerdo de unión civil como un contrato, no se trata de un contrato patrimonial, sino de un acto jurídico de derecho de familia, razón por la cual la autonomía privada se encuentra limitada, es decir, las partes no podrían alterar el contenido imperativamente establecido por la ley, en el sentido que lícitamente no podrían modificarlo o dejarlo sin efecto; de llegar a hacerlo, ese pacto adolecería de objeto ilícito y, por tanto, de nulidad absoluta.

Las razones que permiten sostener que se trata de un acto jurídico de familia son, en primer lugar, la definición legal del acuerdo de unión civil, contenida en el artículo primero de la Ley n. ${ }^{\circ} 20.830$, al señalar que este contrato busca regular los efectos jurídicos de su vida afectiva en común.

Por otro lado, el artículo primero de la referida ley, al señalar que los convivientes civiles son considerados parientes para los efectos señalados en el artículo $4^{2}$ del Código Civil, esto es, para los casos en que la ley señala que debe oírse a los parientes.

En tercer lugar, el hecho que la celebración de este contrato genere un nuevo estado civil, el de conviviente civil, para quienes lo contraigan.

En cuarto lugar, el hecho que este contrato no pueda sujetarse a condición, plazo ni modo alguno, ni pueda ser objeto de promesa.

En seguida, está el hecho que su celebración da origen a un parentesco por afinidad entre uno de los convivientes civiles y los consanguíneos del otro.

Además, debe considerarse que la única forma en que la ley admite su celebración es ante un oficial del Registro Civil.

También se encuentra la circunstancia que no puedan celebrarlo las personas que se hallan ligadas por un vínculo matrimonial no disuelto o por un acuerdo de unión civil vigente.

I89 Historia de la Ley n. ${ }^{\circ} 20.830$, cit. (n. 9), I.055.

I 90 Historia de la Ley n. ${ }^{\circ} 20.830$, cit. (n. 9), r.057.

I9r Historia de la Ley n. ${ }^{\circ} 20.830$, cit. (n. 9), I.ı I4, r. I r6. 
Por otro lado, se debe considerar la circunstancia que de la celebración de este acuerdo deba levantarse un acta, la cual debe ser inscrita en un registro especial a cargo del Servicio de Registro Civil e Identificación.

También resulta relevante el hecho que uno de los efectos del acuerdo sea que los convivientes civiles se deban ayuda mutua y que estén obligados a solventar los gastos generados por su vida en común, de conformidad a sus facultades económicas y al régimen patrimonial que entre ellos exista.

Además, hay que considerar el hecho que proceda la declaración de bien familiar respecto de las parejas que hayan celebrado este acuerdo.

Otro argumento es la circunstancia que el conviviente civil sobreviviente tenga los mismos derechos hereditarios que el cónyuge sobreviviente, incluyendo el derecho de adjudicación preferente.

Por otro lado, se debe considerar el hecho que los asuntos señalados en el artículo $8 .^{\circ}$ de la Ley n. ${ }^{\circ}$ I 9.968, y que se promuevan entre los convivientes civiles, serán conocidos por los tribunales con competencia en materias de familia.

Esta tesis también se apoya en la circunstancia que las inhabilidades, incompatibilidades y prohibiciones existentes entre cónyuges sean aplicables, de pleno derecho, a los convivientes civiles.

También hay que considerar el hecho que sea procedente la compensación económica entre los convivientes civiles.

Finalmente, está la historia fidedigna del establecimiento de la ley, que da cuenta de la evolución que tuvo el proyecto durante su tramitación, desde un contrato que regulaba principalmente aspectos patrimoniales, a un texto definitivo que regula tanto temas personales y afectivos como patrimoniales de familia.

\section{Bibliografía}

Alessandri Rodríguez, A. y Somarriva Undurraga, M., Curso de Derecho Civil. Fuentes de las Obligaciones, Santiago de Chile, Nascimiento, I942.

Barcia Lehmann, R., "La autonomía privada como principio sustentador de la teoría del contrato y su aplicación en Chile”, en De la Maza, I. (editor), Temas de Contratos. Cuadernos de Análisis Furídicos. Colección Derecho Privado III, Santiago de Chile, Ediciones Universidad Diego Portales, Escuela de Derecho, 2006.

Barcia Lehmann, R., Fundamentos del Derecho de Familia y de la Infancia, Santiago de Chile, Thomson Reuters, 20 I I.

Barría Paredes, M., “¿Régimen? de comunidad en el acuerdo de unión civil. Algunas consideraciones sobre su administración y responsabilidad”, en Corral, H. y Manterola, P. (editores), Estudios de Derecho Civil XiI. Ponencias 
presentadas en las XIV Fornadas Nacionales de Derecho Civil, 6 y 7 de octubre de 20 I6, Maitencillo, Santiago de Chile, Thomson Reuters, 2017.

Cornejo Aguilera, P., "Acuerdo de unión civil y derecho internacional privado", en Hernández Paulsen, G. y Tapia Rodríguez, M. (coordinadores), Estudios sobre la Nueva Ley de Acuerdo de Unión Civil, Santiago de Chile, Thomson Reuters, 2016.

Corral Talciani, H., Separación, nulidad y divorcio. Análisis desde los principios y las reglas de la ley de matrimonio civil, Santiago de Chile, Thomson Reuters, 20 I I.

Court Murasso, E., Curso de Derecho de Familia. Matrimonio - regímenes matrimoniales - uniones de hecho, 2. ${ }^{\mathrm{a}}$ ed., Santiago de Chile, Legal Publishing, 2009.

Del Picó Rubio, Jorge, "El Acuerdo de Unión Civil: concepto, elementos y efectos del régimen civil de las uniones afectivas de convivencia en la Ley n. ${ }^{\circ}$ 20.830", Revista de Derecho de Familia, vol. I, n. ${ }^{\circ}$, Santiago de Chile, Thomson Reuters, 2016.

Domínguez Benavente, R. y Domínguez Águila, R., Derecho Sucesorio, 3. a ed., Santiago de Chile, Editorial Jurídica de Chile, t. II, 20 I I.

Elorriaga De Bonis, F., Derecho Sucesorio, 3. ${ }^{\mathrm{a}}$ ed., Santiago de Chile, Thomson Reuters, 2015 .

Esborraz, D., "El concepto constitucional de familia en América Latina. Tendencias y proyecciones", Revista de Derecho Privado, n. ${ }^{2}$ 9, Universidad Externado de Colombia, 2015 .

Gallegos Pérez, N., La teoría del becho y acto jurídico aplicada al derecho familiar, Tabasco, Editorial de la Universidad Juárez Autónoma de Tabasco, 2006.

Garrido Chacana, C., Acuerdo de unión civil. Análisis de la Ley 20.83o, Santiago de Chile, Metropolitana, 20 I 5.

Guarín Ferrer, J., "Autonomía de la voluntad en los contratos de consumo", Ratio Iuris. Revista de Derecho Privado, Universidad de Ciencias Empresariales y Sociales de la Ciudad Autónoma de Buenos Aires, vol. 2, n. ${ }^{2}$, 20 I 4.

Hinestrosa, F., "Autonomía privada y tipicidad contractual”, Revista de Derecho Privado, n. ${ }^{\circ}$ 24, Universidad Externado de Colombia, 20 I 3. 
Historia de la Ley n. ${ }^{\circ}$ 20.830, disponible en http://www.bcn.cl/historiadelaley/ nc/historia-de-la-ley/3990. Última consulta: 30 de enero de 2017.

Lepin Molina, Cristián, Derecho Familiar Chileno, Santiago de Chile, Thomson Reuters, 2017.

López Díaz, C., El acuerdo de unión civil, Santiago de Chile, El Jurista, 20 I 5.

López Díaz, C., Tratado de Derecho de Familia, Santiago de Chile, Digesto, 2 o 6.

Pizarro Wilson, C. y Vidal Olivares, Á., La compensación económica por divorcio o nulidad matrimonial, 3. ${ }^{\text {a }}$ ed., Santiago de Chile, Abeledo Perrot, 2 o Io.

Quintana Villar, M., Derecho de Familia, 2. a ed., Valparaíso, Ediciones Universitarias de Valparaíso, 20 I 5.

Ramos Pazos, R., Derecho de Familia, 7. a ed., Santiago de Chile, Editorial Jurídica de Chile, t. I, 2013.

Rodríguez Grez, P., Instituciones de Derecho Sucesorio, 3. ${ }^{a}$ ed., vol. I, Santiago de Chile, Editorial Jurídica de Chile, 2006.

Ruz Lártiga, G., Explicaciones de Derecho Civil. Sucesiones y liberalidades, Santiago de Chile, Thomson Reuters, t. vi, 20 I4.

Ruz Lártiga, G., Explicaciones de Derecho Civil. Derecho de las personas en familia, Santiago de Chile, Thomson Reuters, t. v, 20 I 2.

Sandoval López, R., Contratos mercantiles, Santiago de Chile, Editorial Jurídica de Chile, 2003.

Troncoso Larronde, H., Contratos, 5. ${ }^{\mathrm{a}}$ ed., Santiago de Chile, Abeledo Perrot, 2010.

Troncoso Larronde, H., Derecho de Familia, i6. ed., Santiago, Thomson Reuters, 2017.

Vidal Olivares, Á., "La compensación por menoscabo económico en la Ley de Matrimonio Civil”, en Vidal Olivares, Á. (coord.), El nuevo derecho chileno del matrimonio, Santiago de Chile, Editorial Jurídica de Chile, 2006. 
Vidal Olivares, Á., “¿Se justifica el reconocimiento de la compensación económica en el acuerdo de unión civil?”, en Acuña San Martín, M. y Del Picó Rubio, J. (editores), Estudios de derecho familiar. Segundas fornadas Nacionales de Derecho de Familia, Talca, Editorial Universidad de Talca, 20 I 7. 